друг другу органов, обеспечивающая эффективное расстановку сил, комплексное использование методов и средств, направленных на решение проблем уголовного судопроизводства, с ведущей и организующей ролью следователя и четким разграничением компетенции участников взаимодействия».

$$
* * *
$$

1. Уголовно-процессуальный кодекс Российской Федерации от 18.12.2001 № 174-Ф3 // Собрание законодательства РФ. 24.12.2001. № 52 (ч. І). Ст. 4921.

2. Белкин Р.С. Криминалистическая энциклопедия. М., 1997.

3. Криминалистика: учебник / Под ред. А.Г. Филиппова. - М.: Юрайт, 2020.

4. Криминалистика: учебник / Под ред. И.Ф. Герасимова, Л.Я. Драпкина. - М., 1994.

5. Хорхоруни А.Х. Взаимодействие органов дознания и предварительного следствия при расследовании преступлений в Вооруженных Силах Республики Армения: Дис. ... канд. юрид. наук. - М., 2004.

6. Хошимов Х.Д. Взаимодействие следователя органов внутренних дел и милиции при расследовании уголовных дел: по материалам Республики Таджикистан: Дис. ... канд. юрид. наук. - M., 2009.

\title{
Вырвина В.В. \\ Понятие и система органов местного самоуправления Российской Федерации
}

Брянский филиал РАНХиГС

(Россия, Брянск)

doi: 10.18411/lj-04-2021-222

\section{Аннотация}

Статья посвящена определению содержания основных понятий и раскрытию системы органов местного самоуправления Российской Федерации. Автор осуществляет анализ теоретических и практических проблем правового регулирования организации местного самоуправления, указывая на особенности деятельности органов местного самоуправления.

Ключевые слова: орган местного самоуправления, представительный орган, публичная власть, полномочия, должностное лицо, муниципальное образование.

\section{Abstract}

The article is devoted to defining the content of the basic concepts and revealing the system of local government of the Russian Federation. The author analyzes the theoretical and practical problems of legal regulation of local government organization, points out the peculiarities of local government.

Key words: local authority, representative body, public authority, authorities, official, municipality.

Конституцией Российской Федерации установлено, что единственным источником власти в Российской Федерации (далее - РФ) является ее многонациональный народ, который осуществляет свою власть непосредственно, а также через органы государственной власти и органы местного самоуправления. Местное самоуправление является одной из основ конституционного строя РФ. В качестве наиболее приближенной к населению власти местное самоуправление обеспечивает защиту тех интересов граждан, которые основаны на совместном их проживании на определенной территории.

Термин «орган местного самоуправления» относится к конституционным терминам - он используется в статьях 3,12,15, 24, 32, 40, 46, 97, 130, 131, 132 Конституции РФ. В Федеральном законе №131- Ф3 определение этого термина изложено в следующей редакции: органы местного самоуправления - избираемые 
непосредственно населением и (или) образуемые представительным органом муниципального образования органы, наделенные собственными полномочиями по решению вопросов местного значения.

Таким образом, органы местного самоуправления - это органы самоуправляющихся территориальных сообществ, каковыми, по сути, являются муниципальные образования. Данные органы ы формируются непосредственно населением либо представителями населения (представительным органом) и несут ответственность за ненадлежащее осуществление своих полномочий, прежде всего перед жителями муниципального образования. Им принадлежит особое место в демократической системе управления обществом и государством, и оно определяется, прежде всего, тем, что наличие органов самоуправления обеспечивает такую децентрализацию системы управления, которая делает эту систему наиболее пригодной к обеспечению интересов населения на местах с учетом исторических и иных местных традиций.

В основе формирования системы органов местного самоуправления лежит принцип многообразия организационных форм местного самоуправления. Этот принцип относится к числу базовых принципов организации местного самоуправления и предполагает определенный простор для населения в выборе институтов выражения своих интересов на муниципальном уровне.

Систему органов местного самоуправления составляют представительный орган муниципального образования, глава муниципального образования, местная администрация (исполнительно-распорядительный орган муниципального образования), контрольный орган муниципального образования, иные органыместного самоуправления, предусмотренные уставом муниципального образования и обладающие собственными полномочиями по решению вопросов местного значения. Наличие в системе органов местного самоуправления представительного органа муниципального образования, главы муниципального образования, местной администрации (исполнительно-распорядительного органа муниципального образования) является обязательным, за исключением случаев, предусмотренных законом. Наряду с наличием органов местного самоуправления предполагается возможность создания отраслевых (функциональных) и территориальных органов местной администрации (п. 8 ст. 37 Федерального закона № 131-Ф3).

Система органов местного самоуправления в случае образования на межселенных территориях вновь образованного муниципального образования или в случае преобразования существующего муниципального образования определяется населением на местном референдуме в муниципальном образовании с численностью населения менее 100 человек (на сходе граждан) или представительным органом муниципального образования и закрепляется в уставе муниципального образования.

Решение представительного органа муниципального образования об изменении структуры органов местного самоуправления вступает в силу не ранее чем по истечении срока полномочий представительного органа муниципального образования, принявшего указанное решение.

Таким образом, существенными признаками органов местного самоуправления являются следующие:

1. таковые должны быть избраны (сформированы) населением муниципального образования на муниципальных выборах или образованы представительным органом муниципального образования;

2. таковые должны обладать собственными полномочиями по решению вопросов местного значения;

3. статус таковых как органов местного самоуправления и их собственные полномочия должны быть предусмотрены уставом муниципального образования. 
Перечисленные три существенных признака органа местного самоуправления должны присутствовать одновременно, что и составляет основу его статуса.

$$
* * *
$$

1. Конституция Российской Федерации (принята всенародным голосованием 12.12.1993) (с учетом поправок, внесенных Законами РФ о поправках к Конституции РФ от 30.12.2008 № 6-ФКЗ, от 30.12.2008 № 7-ФКЗ). «Российская газета», № 7, 21.01.2009

2. Федеральный закон от 06.10.2003 № 131-Ф3 (ред. от 03.05.2011) «Об общих принципах организации местного самоуправления в Российской Федерации» (принят ГД ФС РФ 16.09.2003). «Российская газета», № 202, 08.10.2003.

3. Авакьян С.А., Лютцер В.Л., Пешин Н.Л. и др. Муниципальное право России. М.: Проспект, 2011. C. 158

4. Бабичев И. В. Муниципальное право: системно-структурный анализ юридических конструкций. М. : Норма : ИНФРА-М, 2010. 188 с.

\section{Гусейнов Н.Р., Шарипова Э.А. \\ К вопросу о роли административно-процессуального нормотворчества при осуществлении государственного контроля}

Башкирский государственный университет

(Россия, Уфа)

doi: 10.18411/lj-04-2021-223

\section{Аннотация}

Административный процесс - это упорядоченная система административнопроцессуальных норм и основанная на них деятельность органов и должностных лиц. Ведомственное административно-процессуальное нормотворчество, регламентирующее осуществление государственного контроля разнообразно, и только в последнее время законодатель задумался об общих требованиях в вопросах его регулирования. Поскольку осуществление государственного управления невозможно без государственного контроля, а государственный контроль неосуществим без конкретных административных процедур, авторы приходят к выводу, что административный процесс следует изучать как отдельную учебную дисциплину в высших юридических учебных заведениях.

Ключевые слова: административный процесс, административнопроцессуальное нормотворчество, административное право, исполнительная власть, государственный контроль (надзор).

\section{Abstract}

The administrative process is an orderly system of administrative and procedural rules and the activities of bodies and officials based on them. Departmental administrativeprocedural rulemaking, which regulates the exercise of state control, is diverse, and only recently the legislator has thought about general requirements for its regulation. Since the exercise of public administration is not possible without State control, and State control is not feasible without specific administrative procedures, the authors conclude that the administrative process should be studied as a separate educational discipline in higher legal institutions.

Key words: administrative process, administrative-procedural norm-setting, administrative law, executive power, state control (supervision).

Понятия «административный процесс» и «государственный контроль» и их содержание действительно являются предметом для острых дискуссий уже многие годы. Взаимосвязи государственного контроля и административно-процессуального нормотворчества субъектов контроля, к сожалению, в научной литературе уделяется не так много внимания. В теории административного права государственный контроль в системе органов исполнительной власти традиционно осуществляют такие субъекты 